\title{
Tourists' Perceived Risk and Image of Destinations Prone to Natural Disasters: The Case of Bali and Yogyakarta, Indonesia
}

\author{
Erda Rindrasih \\ Utrecht University, the Netherlands \\ Email: E.Rindrasih@uu.nl
}

\begin{abstract}
Tourism has emerged as one of the largest and most rapidly growing economic sectors in the world. Nevertheless, many tourist destinations have been periodically confronted by natural disasters that threaten their survival as an industry by negatively impacting their image and safety perception. This research assessed tourists' perception of the risk and images of a destination that is considered prone to natural disasters, by surveying 537 tourists in Yogyakarta and Bali. This study contributes to the debate on tourism development issues related to negative perceptions and images that have discouraged prospective tourists from visiting affected destinations. The results of the survey indicated that the occurrence of past disasters did not strongly influence tourists' decision to visit Indonesia. Instead, the creation of the destination image was informed more by its current situation, and it is these current factors that may encourage or discourage potential tourists. These findings should signal to tourism planners that while environmental disasters are unavoidable, post-disaster rehabilitation of a destination's image would significantly increase its chances of rebounding quickly.
\end{abstract}

Keywords: perception; image; risk; disaster; tourists

\section{INTRODUCTION}

Tourism has undergone extraordinary growth and diversification over the past few decades and has become one of the world's fastest-growing economic sectors (UNWTO, 2013). The number of international tourist arrivals has continually increased and is predicted to grow by 3.3 per cent per year between 2010 and 2030 (UNWTO, 2013). As a consequence of this, the tourism industry plays an increasingly important role in the world economy, because of its benefits in providing more job opportunities in innovative market segments (Javalgi \& White, 2002).

Despite its fast growth, the travel and tourism industry has experienced many challenges, especially in the last two decades. The first decade of the $21^{\text {st }}$ century has been referred to as one of "many perfect storms" for the industry (Chiesa, 2009), beginning in the United States with the attacks on $11^{\text {th }}$ September 2001 and ending in the midst of the worst economic crisis since the Great Depression (Morgan, Pritchard, $\&$ Pride, 2011). The decade was also marked by the wars in Iraq and Afghanistan, outbreaks of Severe Acute Respiratory Syndrome (SARS), avian flu, and swine flu, and many devastating natural and humaninduced environmental disasters. An increasing frequency of natural disasters was recorded after the Indian Ocean earthquake and tsunami in 2004, which killed more than 283,100 people, making it one of the deadliest disasters in modern history. Other circumstances also contribute to the negative image and perceptions of a tourist destination, such as political and social instability, poor governance, terrorism, crime, health problems, unfriendly hosts, 
cultural and language barriers, primitive conditions, economic concerns, and persistent and unfounded rumours and myths, all of which may discourage tourists from traveling to the destination (Carter, 1998; Sönmez \& Graefe, 1998; Cohen-Hattab \& Kerber, 2004).

Although the risks and challenges are intense, only a few studies have been conducted to understand the image and perceived risk of a tourist destination that has had a natural disaster in the past (e.g. Baxter \& Bowen, 2004; Beerli \& Martin, 2004; Hunter-Jones Jeffs, \& Smith, 2008; Lepp, Gibson, \& Lane, 2011; Park \& Reisinger, 2010; Ritchie, 2009; Sjöberg, 2000; Sönmez \& Graefe, 1998). This paper aimed to fill the gap by assessing the perceived risk and the image of a tourist destination after a catastrophic natural disaster. Indonesia was chosen as the location of this case study, as it is one of the nations that strives to boost its economy by targeting $20 \%$ of its total gross domestic product to originate from the tourism industry (Pikiran Rakyat, 2016). Moreover, the geographical location and geological characteristics of Indonesia challenge the performance of the tourism industry, as intense tectonic activities often trigger earthquakes and tsunamis, while volcanic activities cause earthquakes and eruptions. This condition is exacerbated by the fact that disaster management remains difficult in Indonesia, especially when it concerns the tourism industry. Negative headlines about natural disasters often appear in the media especially during the extreme rain and dry seasons This paper is expected to contribute to the tourism development debate on the relationship of tourism and disasters. Furthermore, the research herein sought to answer the question of how tourists perceive the image and risk of Indonesian tourism and how this perception influences their decision to visit Indonesia.

The following section discusses the conceptual framework of the research, focusing on tourist destination images, real risks, risk perception, and the roles of image and perception in influencing the behaviour of tourists. Section three explains the methods used in this research, followed by the context of Indonesia as the location of the case study in the fourth section. Section five presents the survey findings and analysis. The findings are discussed in section six to gain some insights based on previous research. Finally, section seven concludes the article by presenting the summary, recommendations, and possibility of future research.

\section{LITERATURE REVIEW \\ Image and disaster risk perception of a tourism destination}

The term "risk" is connected with the expression of hazard, a probability of danger, consequence, potential adversity, and threat (Slovic, 2002). Slovic (2002) defined risk as a social construction that emerges as a response to danger and uncertainty, and risk is always a subjective evaluation in understanding both the probability of danger and consequences. A risk is also defined as the probability of hazard occurrence (Smith, 2013). Risk estimation can express the risk perceptions associated with a risk factor, as well as the uncertainty of the knowledge about risk factors (Fischhoff, 2002). In addition, personal vulnerability in risk perception is expressed as bias and inconsistency.

Availability and accessibility of information are the main factors behind individuals and social groups' risk perception. Each has a different judgment of the risk of certain destinations, because they do not have the same information about the probability of disaster events. For instance, each individual in a community may assess the risk of "flood" very differently, because they do not have the same information about the probability of flood hazard events in their region and/or lack information of flood mitigation measures and their effectiveness. Furthermore, each individual perhaps has a different historical background regarding the experience of living in a floodplain and of being flooded.

Risk perceptions can generate much wider losses, especially when a disaster happens in a tourist destination whose economy is susceptible to disaster-based instability. The significance of risk perception in the field of tourism has been recognized in several studies. Moirera (2008) mentioned that risk perception is mainly influenced by the distribution of the impacts over time. The success of tourist destinations depends on the perceived image tourists and residents have of them in the present reality and the future. Moreover, stealth risks are considered higher risks than catastrophic risks (Moreira, 2008).

In addition to the perception of its risk, the image of a destination has been believed to have an impact on demand in the tourism industry. Since the 1970s, tourist destination images have become one of the dominant areas of tourism research (Hosany, Ekinci, \& Uysal, 2006). This image is defined as an attitudinal concept composed of the sum of the beliefs, ideas, and impressions that a tourist holds for 
a destination (Crompton, 1979). Hunt (1975) defined an image as a "perception held by potential visitors about an area". Meanwhile, Phelps (1986) defined an image as "perceptions or impressions of a place". Gartnerand \& Hunt (1987) stated that an image is "impressions that a [person] ... holds about an area in which they do not reside". Gartner (1989) saw an image as "a complex combination of various products and associated attributes".

Many authors agree that the study of tourist destination images emerged from Hunt's work in 1971 (Gallarza, Saura, \& García, 2002). Hunt described various approaches to the study of tourist destination images from 1971 to 1999 . They mainly focused on several approaches, such as: 1) conceptualization and dimension, 2) the destination image formation process, both static and dynamic, 3) the assessment and measurement of a destination image, 4) the influence of distance on a destination image, 5) destination image change over time, 6) the active and passive roles of residents in an image study, and 7) destination image management policies, such as promotion, positioning, and so on. In addition, Leiper (2000) believes that a destination image depends upon the tourists' perception of its ability to satisfy their needs.

According to Andreu, Bigné, and Cooper (2001), the perceived image often does not match the tourist destination's reality. Morgan et al. (2004) and Echtner \& Ritchie (2003) viewed the image of a tourist destination as the outcome of different factors and elements, which serve to form the specific image of a country. It is a general idea people have in mind about a location, a destination stereotype (Pearce, 1988). Furthermore, potential tourists have individually formed images about a tourist destination based on their own experiences. Hall \& O'Sullivan (1996) suggested three main elements that create a destination image and influence decision making and behaviour: 1) returning tourists through wordof-mouth reporting upon their return; 2) the media through their reporting and image-making, and 3 ) the government through their policies and strategies.

\section{The impact of the perceived risk and image of a destination on tourists' behavior}

Crisis and disaster can create a negative destination image, ultimately affecting consumer confidence, the decision-making process, and eventually destination choice and behaviour (Ritchie, 2009).
Reduced tourism demand has been influenced by the discouragement of tourists to visit the destinations. According to Maslow's theory, when the safety and security cannot be fulfilled, the higher needs cannot be satisfied, one of which is self-fulfilment through travel. The choice of a destination is based on the awareness, availability, and positive perception of it (Woodside $\&$ Sherrell, 1997). Furthermore, awareness is a direct result of the destination image. It is determined by decision or constraint factors, such as the availability of time and money, distance, and the availability of travel companions.

Many researchers agree that perceived risk influences behaviour (Brug et al., 2004; Sjöberg, 2000; Weinstein, 1988). Kozak, Crotts \& Law (2007) mentioned that poor of safety and security could impact a country's tourism and travel industry because of the negative word-of-mouth communication. Moreira (2008) mentioned that risk perception is an element of the general perceived image of products or services, and it is found to have a critical impact on organizational results. A study conducted by McKercher and Pine (2006) revealed that although only $0.2 \%$ of Hong Kong's population was impacted by the SARS outbreak, tourism demand dropped significantly, as did the associated revenue. Sensationalist media, their analysis showed, had over-reported the threat of SARS (McKercher \& Pine, 2006). Moreover, Chen \& Noriega (2004) found that $58 \%$ of respondents reported travelling less as a result of the attacks on $11^{\text {th }}$ September.

There is a difference between image and satisfaction. The latter largely depends on a comparison of expectations based on previously held images and the actual reality encountered at the destination (Chon, 1990). Most researchers agree that the image of a tourist destination needs to match its local conditions, characteristics, inhabitants, and culture. Therefore, a positive image is important to attract tourists, but it does not generate the satisfaction. Also, Gartner \& Gartner (1996) specified that a destination's image is vital in the set of variables that influence destination choice and the travel process. The negative image of a destination may significantly impact its competitiveness because an image has a role in determining visitor choice and the destination's reputation (Konecnik, 2004).

To date, the literature on the destination image has elucidated on a number of important issues, such as conceptualization and dimensions, the destination image formation process (static and dynamic), 
assessment and measurement of the destination image; the influence of distance on the destination image, changes in a destination image over time, and the active and passive roles of residents in image study and destination image management policies (Gallarza, Saura, \& Garcia, 2002). In this research, the destination image is combined with risk perception, taking into account the destination's high proneness to natural disasters. The conceptual framework is: risk $\rightarrow$ image of the destination $\rightarrow$ perceived risk $\rightarrow$ decision to visit $\rightarrow$ recommendation to visit.

\section{METHODS}

\section{Survey locations}

Indonesia was selected as the case study location for several reasons. First, Indonesia is in the process of boosting its tourism industry as part of its economic development initiative, and received more than 12 million tourists in 2017, which contributed to almost $9 \%$ of its total national income. Second, its growth is accompanied by threats from natural disaster-related crises. Its location in the Pacific Ring of Fire leads to a geological instability. Yogyakarta and Bali were chosen as the survey locations because both are popular tourist destinations while at the same time considered prone to natural disasters. Interviews were conducted at locales frequented by tourists, such as beaches, cafés, tourism villages, and temples, including Kuta Beach, Seminyak Beach, Ulu Watu Beach, Candi Borobudur, Candi Prambanan, Prawirotaman, and Malioboro Street. To minimize bias, respondents were categorized based on their continent of origin, with 40 to 60 respondents representing each continent (Africa, America, Australia, Europe, Asia, Australia, and the Pacific).

\section{Survey instruments}

The questionnaire consists of three sections:

- General section. The general section detailed the respondent characteristics, such as age, education, and country of origin. The age and education subsections were in a multiplechoice format, where respondents could match their data with a list of options.

- Tourist's perceived risks. The second section consisted of questions with multiple choices from which the respondents were required to select one based on their preference. A Likert scale with five response options was used in this section (very agree, agree, doubt, disagree, and very disagree). The respondent's perception of the risk of natural disaster in the destination was gathered by requesting the respondent to answer the structured questionnaire. There were four overarching statements to investigate the tourists' perception of safety, risk, decision to visit, and recommendation, namely (1) Indonesia is a safe country to be visited; (2) Indonesia has a high risk of natural disasters; (3) The disaster will not influence my decision to visit Indonesia; and (4) I will recommend the destination to my family and friends.

- Tourist's image. Section three of the questionnaire asked the respondents to list five words illustrating Indonesia.

\section{Data analysis}

Data from a total number of 537 respondents were collected in Bali and Yogyakarta. The data were then entered into the SPSS program and a descriptive analysis was run. The comparison of the percentages wan then assessed to gain the tendency of the answer. Additionally, the image data were determined based on the words given by the respondents. These words were categorized into three groups - positive, neutral, and negative - to gain insight into the most common words stated by the respondents.

\section{Context of Indonesia}

Indonesia is considered the largest economy in Southeast Asia and is one of the emerging market economies because of its large population and abundance of natural resources. There are several hazard risks associated with Indonesia, geologically and geographically. The potential hazards in Indonesia can be classified as follows: 1) geological hazards, such as an earthquake, tsunami, or volcanic eruption; 2) hydro-meteorological hazards, such as a flood, landslide, storm, drought, or forest fire; 3 ) biological hazards, such as avian influenza; and 4) technological failures, such as an industrial accident. The disaster event increases in terms of frequency, with 70 percent of the events considered hydro-meteorological disasters (Maarif, 2014).

In a global report, Indonesia ranks $12^{\text {th }}$ in countries with a high mortality risk due to the multiple hazards. It was estimated that 40 percent of the total inhabitants were highly vulnerable to natural hazards, such as earthquakes (10 deaths/ 
year/million inhabitants) and tsunamis (8 deaths/ year/million inhabitant). As an archipelagic country, the vulnerability of Indonesia may be worsened by climate change, especially in the case of its smaller islands. Table 1 shows some of disaster events in Indonesia in the last decade.

\section{RESULTS AND ANALYSIS}

\section{Respondents' profiles}

Table 2. Overall data of respondents.

\begin{tabular}{|c|c|c|c|}
\hline Variable & Characteristic & $n i$ & Percentage \\
\hline Gender & $\begin{array}{c}\text { Male } \\
\text { Female }\end{array}$ & $\begin{array}{l}302 \\
235\end{array}$ & $\begin{array}{l}56.2 \\
43.8\end{array}$ \\
\hline Age & $\begin{array}{c}<20 \\
20-29 \\
30-39 \\
40-49 \\
50-59 \\
>60\end{array}$ & $\begin{array}{c}91 \\
264 \\
86 \\
49 \\
45 \\
2\end{array}$ & $\begin{array}{c}16.9 \\
49.2 \\
16 \\
9.1 \\
8.4 \\
0.4\end{array}$ \\
\hline Continent & $\begin{array}{c}\text { Asia } \\
\text { Africa } \\
\text { America } \\
\text { Europe } \\
\text { Australia } \\
\text { Domestic }\end{array}$ & $\begin{array}{c}77 \\
8 \\
68 \\
111 \\
60 \\
213 \\
\end{array}$ & \begin{tabular}{c|}
14.3 \\
1.5 \\
12.7 \\
20.7 \\
11.2 \\
39.7
\end{tabular} \\
\hline $\begin{array}{c}\text { Education } \\
\text { level }\end{array}$ & $\begin{array}{c}\text { Did not } \\
\text { complete high } \\
\text { school } \\
\text { High school } \\
\text { Diploma } \\
\text { Bachelor } \\
\text { Master } \\
\text { PhD }\end{array}$ & $\begin{array}{c}4 \\
\\
199 \\
84 \\
183 \\
62 \\
5\end{array}$ & $\begin{array}{c}0.7 \\
\\
37.1 \\
15.6 \\
34.1 \\
11.5 \\
0.9\end{array}$ \\
\hline $\begin{array}{l}\text { Length of } \\
\text { Stay }\end{array}$ & $\begin{array}{c}<5 \text { days } \\
5-10 \text { days } \\
11-20 \text { days } \\
21-30 \text { days } \\
>31 \text { days }\end{array}$ & $\begin{array}{c}202 \\
110 \\
57 \\
47 \\
121\end{array}$ & $\begin{array}{c}37.6 \\
20.5 \\
10.6 \\
8.8 \\
22.5\end{array}$ \\
\hline
\end{tabular}

A total of 537 questionnaires were completed (Table 2), with 295 filled in by respondents in Bali (55 percent) and 242 in Yogyakarta (45 percent). The number of male respondents (56.2 percent) was greater than female respondents ( 43.8 percent), although the difference was acceptable for an equal representation of each gender. In terms of number of visits, 325 respondents (56.6 percent) were first-time visitors, and 28.1 per cent of respondents had visited Indonesia more than three times. Additionally, respondents' ages were predominantly in the range of 20-29 years old; respondents outside of this range were distributed somewhat proportionately across age groups. The respondents' country of origin consisted of Asia (China, Hong Kong, India, Japan, Korea, Malaysia, Saudi Arabia, Singapore, Thailand, and Vietnam); Africa (Democratic Republic of Congo, Madagascar, South Africa, Sudan, Tanzania, and Tunisia); America (United States of America, Argentina, Brazil, Canada, Chile, Czech Republic, Mexico, Paraguay, Peru, and Uruguay); Europe (Austria, Belgium, Denmark, United Kingdom, Finland, France, Germany, Netherland, Ireland, Italy, Portugal, Russia, Spain, Sweden, Switzerland, and Ukraine); and Australia and the Pacific (Australia and New Zealand).

\section{Image of Indonesia in Words}

Respondents were asked to illustrate the destination in five words (Table 3). Ultimately, 334 words were used to describe the destination. These can be categorized into three classes: positive image, negative image, and neutral image. Positive words were identified based on the inclination of being positive, such as revealing excitement, a good image, good memory, good experience, and a good sense of place. These words implied the affirmative and progressive sense of the destination. The survey revealed 118 positive words, the two most common of which were "beautiful" and "friendly".

Neutral words comprise those that have no positive or negative meaning. Mostly, these words referred to a place, activity, art, or location. There were 95 words that were categorized as neutral, with "beach" and "hot" being the most common. These words reflect how Indonesian tourism is perceived and imaged by the tourists, and could serve as important inputs for decision makers in developing their branding.

Negative words signify a bad image of Indonesia. The most common of these words were "congestion", "corrupt", and "crowded". The survey results showed no single mention of words associated with "natural disaster", whether by domestic or foreign tourists, the word destruction were indicated the environmental destruction due to the human induced activities. The words largely implied the present condition of the destination, and did not mention a condition in the past. 
Table 1. Examples of devastating disasters in Indonesia in the last decade.

\begin{tabular}{|c|c|c|}
\hline Natural Disaster & Time & Casualties \\
\hline Tsunami, the Province of Aceh & 26 December 2004 & 126,000 people dead \\
\hline Merapi Eruption, Province of Central Java and Yogyakarta & 5 November 2010 & 200 people dead \\
\hline Earthquake, Yogyakarta Special Province & 27 May 2006 & 6,000 people dead \\
\hline $\begin{array}{c}\text { Earthquake and tsunami in Mentawai Regency, the } \\
\text { Province of West Sumatra }\end{array}$ & 25 October 2010 & 400 people dead \\
\hline Earthquake Tasikmalaya, the Province of West Java & 2 September 2009 & 73 people dead \\
\hline Earthquake in Padang city, West Sumatra & 30 September 2009 & 6,234 people dead \\
\hline Earth quake Nabire, Papua & 26 November 2004 & 27 people dead \\
\hline Wasior Flood, West Papua & 4 October 2010 & $\begin{array}{c}158 \text { people dead and } \\
145 \text { lost }\end{array}$ \\
\hline Sinabung Volcano Eruption & January-February 2014 & 17 people dead \\
\hline
\end{tabular}

Table 3. Words the respondents used to illustrate Indonesia.

\begin{tabular}{|c|c|}
\hline $\begin{array}{l}\text { Positive image } \\
\text { (118 words) }\end{array}$ & $\begin{array}{l}\text { Adventurous, aesthetic, affordable, amazing, animal, art, attractive, authenticable, } \\
\text { awesome, beautiful, better, big, blue, calm, caring, changing, cheap, classic, clean, close, } \\
\text { colourful, re-coming, comfort, cool, dazzled, delicious, delight, easy, growing, enjoy, } \\
\text { enthusiasm, evolution, excellent, exiting, exotic, family, fantastic, fascinating, flora \& } \\
\text { fauna, folklore, food, free, fresh, friendly, diversity, fun, richness, gentle, genuine, gift, } \\
\text { glamour, God, good, gotong-royong, gracious, great, green, haggle, happiness, less- } \\
\text { stress, lively, love, magic, maintained, neat, developed, nice, open-minded, orderly, } \\
\text { party, peace, perfect, plurality, polite, potential, pretty, quite, recommendable, respectful, } \\
\text { rich culture, romantic, hospitality, safe, save, scenery, sex, smile, diving, sociable, } \\
\text { subhanallah, tasty, tolerant, top, heart-warming, heaven, great, helpful, historical, } \\
\text { holiday, home, honeymoon, honourable, hospitality, humorous, important, impress, } \\
\text { improvement, incredible, interesting, inviting, kind, large, memory, metamorphism, } \\
\text { modesty, unbelievable, sustain, surprising, secure, unique, welcoming, wow, wonderful, } \\
\text { wisdom, spellbound, cost effective, thrilling. }\end{array}$ \\
\hline $\begin{array}{c}\text { Neutral } \\
\text { (95 words) }\end{array}$ & $\begin{array}{l}\text { Access, Asia, accommodation, auto bike, back, Bali, batik, beach, beer, Beringharjo, } \\
\text { boat, Borobudur, building, canoe, ceremony, climate, club, cold, community, core, } \\
\text { culinary, cultural, dance, different, forest, golf, handicraft, Hindu, human, Indonesia, } \\
\text { international, Islam, island, playground, Kuta, landscape, language, lumpia, Malioboro, } \\
\text { moped, motorbike, mountain, museum, mushroom, music, muslim, naïve, nasi lemak, } \\
\text { Ngobaran, night, ocean, palm oil, Parangtritis, people, pilgrim, Prambanan, rain, religion, } \\
\text { rice, sand, sea, service, shopping, similarity, something, spice, spirit, sport, sprawling, } \\
\text { street, sun, surf, sweat, tea, temple, tourism, tradition, vacation, variation, vendor, view, } \\
\text { volcano, waive, walk, warm, water, wealthy, weather, westernized, wet, white sand, wild, } \\
\text { woman, world. }\end{array}$ \\
\hline $\begin{array}{l}\text { Negative } \\
\text { (42 words) }\end{array}$ & $\begin{array}{l}\text { Boring, busy, chaos, confusing, corrupt, crazy driver, crowded, dangerous fauna, } \\
\text { destruction, dirty, disorganized, drugs, drunk, expensive, hot, hurt animal, inefficient, } \\
\text { lack infrastructure, late, lacking, littering, mystic, misunderstanding, over congestion, } \\
\text { passive, patriarchal, plastic, pollution, poor, poverty, bad transportation, remote, rubbish, } \\
\text { low salary, small road, smoke, terrorism, theft, waste, uneducated, unsure safety, } \\
\text { unorganized. }\end{array}$ \\
\hline
\end{tabular}




\section{Perceived risks}

\section{Q1. Indonesia is a safe country to visit}

Respondents were asked to respond to the statement, "Indonesia is a safe country to visit." The results showed that $40 \%$ of the domestic tourists responded with "agree" and 24\% with "very agree" (Figure 1). Foreign tourists were even more positive, with $61 \%$ responding that they "agree" and 14\% that they "very agree". In terms of the "doubt" answers, the domestic tourists showed a higher percentage $(27 \%)$. Thus, it can be said that the majority of tourists perceived Indonesia as a safe place to visit.

Figure 1. Respondents' answers to the statement, "Indonesia is a safe country to visit."
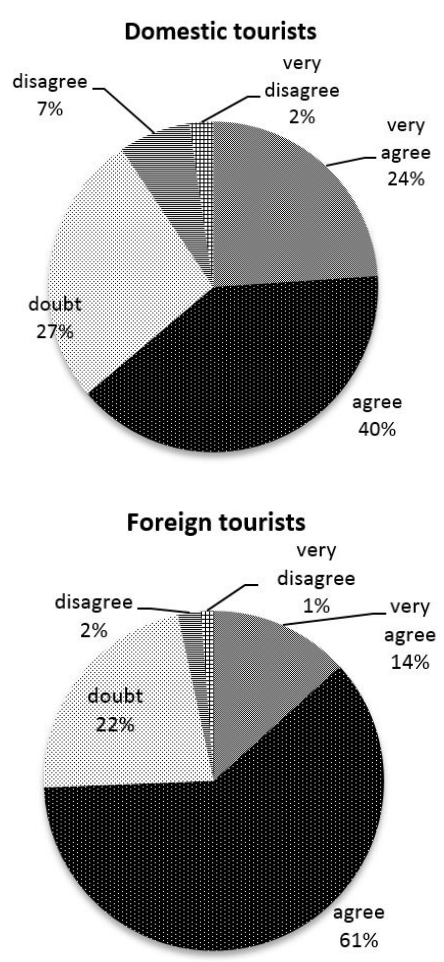

\section{Q2. Indonesia has a high risk of natural disasters}

The second statement in section 2 of the questionnaire was, "Indonesia has a high risk of natural disasters." With this statement, respondents' knowledge and understanding of past natural disasters were investigated. Indonesia has experienced various natural disasters in the past two decades, which have garnered massive media coverage, both nationally and internationally. Using this statement, the research is expected to gain an understanding of whether tourists had prior knowledge of the risk of the destination, which reflected their awareness of potential threats in the location.

The results of the survey revealed that domestic tourists tended to agree or highly agree with the second statement (Figure 2). Only 2 percent of the domestic respondents disagreed, while 11 per cent expressed doubt. For the foreign tourists, the majority also agreed (52 percent), although a high proportion (33 percent) also expressed doubt. Taken together, this indicates that the majority of both foreign and domestic tourists perceived Indonesia as having a high risk of natural disasters.

Figure 2. Respondents' answers to the statement, "Indonesia has a high risk of natural disasters."
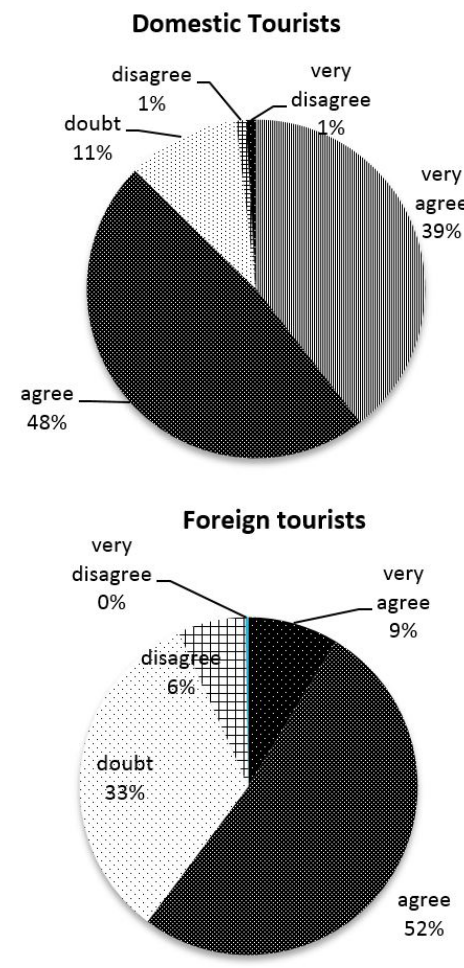

\section{Q3. A disaster will not influence my decision to visit Indonesia}

The next statement, "A disaster will not influence my decision to visit Indonesia," was received with similar responses across both tourist groups (Figure 3 ). The majority of domestic respondents agreed that a disaster would not influence their decision to visit Indonesia (94 per cent), while 50 per cent of the foreign tourists gave the same response. Meanwhile, 27 per cent of the latter group said they "very agree". Therefore, it can be concluded that, in general, the 
respondents will not be influenced by the occurrence of a disaster in their decision to visit Indonesia.

Figure 3. Respondents' answers to the statement, "A disaster will not influence my decision to visit Indonesia."
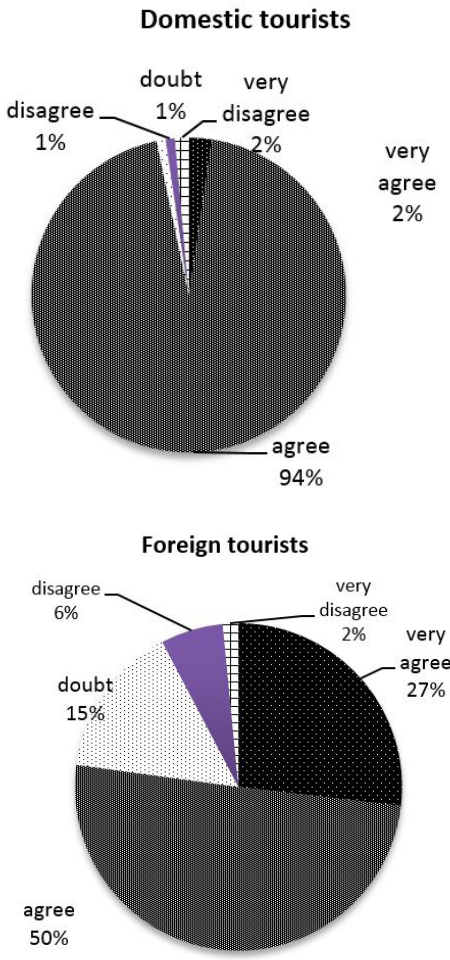

\section{Q4. I will recommend the destination to my family and friends}

The final statement of this portion of the questionnaire was, "I will recommend the destination to my family and friends." This question was asked to find out whether the respondents would recommend the destinations (in this case, Bali and Yogyakarta) to their family and friends. The recommendation of the destination to other potential tourists implies their satisfaction with the destination, as well as their loyalty toward it (Ramseook-Munhurrun, Seebaluck, \& Naidoo, 2015). The majority of the domestic tourists agreed or highly agreed to recommend the destination to their family and friends (Figure 4). Similarly, 41 per cent of the foreign tourists agreed to the statement and even greater percentage highly agreed (47 per cent). In general, both domestic and foreign tourists would recommend the destinations to their family and friends.
Figure 4. Respondents' answers to the statement, "I will recommend the destinations to my family and friends."
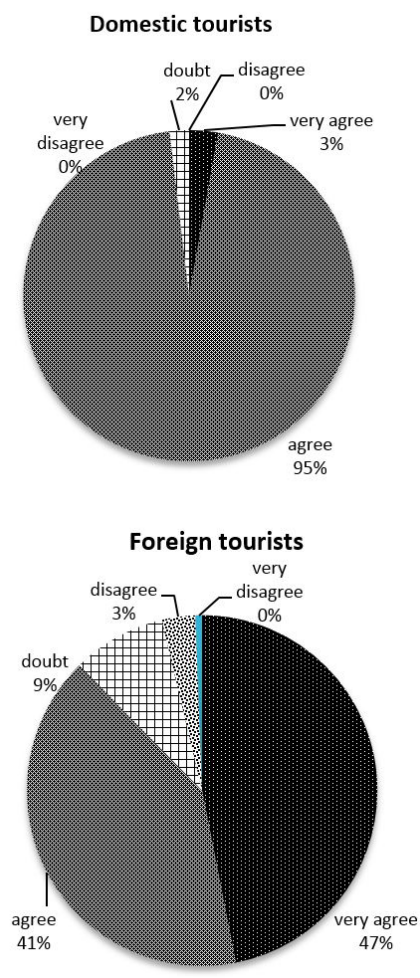

\section{DISCUSSION}

Currently, tourist destinations exist in a highly competitive environment, and the competition and challenges they face are only set to intensify in the years to come. One of the unavoidable challenges to destinations is the omnipresence of natural disasters, which could discourage tourists from visiting the destination because of their effect on the tourists' perception of safety. Consequently, research on the relationship between tourism and disasters is essential to gain a better understanding of what the tourists' perceived risk and image of the destination are, particularly if they are located in areas prone to natural disaster events.

\section{Image of destination in words}

In relation to the image derived by the tourists, previous studies (e.g. Baloglu \& McCleary 1999; Chon, 1990) demonstrated that a destination image would influence the destination selection process, the subsequent evaluation of the trip, and their behaviour in planning future travels. More favourable or positive 
images will increase the likelihood of returning to the same destination. There is an impulse that a positive image of a tourist destination can indicate satisfaction of visits. Several authors, such as Hallowell (1996) and Rust \& Zahorik (1993), have highlighted a link between satisfaction and post-purchase behaviour. They believe that satisfaction affects tourist retention. More recent studies have also attempted to understand whether loyalty is more important than satisfaction, particularly marketing-based literature such as Anderson \& Sullivan (1993), Cronin et al. (2000), and Taylor \& Baker (1994).

In order to find the position of this article in the debate of tourism study and disasters, this research attempted to provide evidence of what tourists have imaged about the destination. It is in line with some studies that suggest that the image of a destination can be positive, negative, or neutral. The majority of words respondents chose to use to describe Indonesia were positive, such as "beautiful" and "friendly". Neutral words included "beach" and "hot", while negative words include "crowded", "congestion", and "corrupt". It was found that the tourists were mainly focused on the image of an existing condition and overlooked past situations (in which the occurrence of a disaster would fall). There was no single word chosen that could be associated with past natural disasters, such as "tsunami", "earthquake", "floods", "hurricane", or "landslide". However, the word "terrorist" and "destruction", a human-induced disaster, was mentioned by some of the respondents, which could be associated with the terrorist attacks in Bali in 2002 and 2005.

\section{Tourists' Perceived Risk}

The survey revealed several findings that could serve as important inputs to build the destination image and reduce perceived risks of Indonesian tourism. First, Indonesia is perceived as a safe country to visit, as the majority of the respondents indicated. The high percentage of agreement demonstrates that although many natural disasters have occurred in the past, there was a specific segment of tourists who continued visiting Indonesia regardless. In other words, improving tourism promotion and preparing for the possibility of disaster events can obtain a better perception.

Second, the majority of tourists acknowledged the high risk of disaster in the destination. These results are compelling, as in fact, they had just arrived at their destinations when they filled in the questionnaire. The knowledge of the high risk of natural disasters did not strongly discourage them from making the visit. It is likely that their perception of the possible occurrence of a disaster did not influence their decision to visit the destination. However, this paper agrees that a natural disaster event may disrupt tourist flow, even if past events are not likely to affect the decision, especially after the destination has recovered from a previous event.

Third, the fact that the respondents participated in the survey in the destination makes the result more interesting. The majority of the respondents understood that natural disasters had happened in Indonesia in the past, but they seem to have had little influence on the tourists' decision to make their first or returning visit to Indonesia. In other words, the government and tourism managers had successfully restored the destination.

Finally, the majority of tourists, both foreign and domestic, agreed to recommend their respective destinations to their families. Although the tourists had knowledge of past natural disasters, and were cognizant of the possibility of their reoccurrence in the future, they would still recommend the destinations to their families and friends. The high percentage of the respondents recommending the destination to their families and friends may indicate their satisfaction, corroborating the empirical evidence that a tourist's satisfaction is one of the indicators that a tourist will return and/or recommend the destination to other potential tourists, as observed in a number of other studies (Beeho \& Prentice, 1997; Bramwell, 1998; Juaneda, 1996; Kozak, 2001; Kozak \& Rimmington, 2000; Ross, 1993; Yoon \& Uysal, 2005).

\section{CONCLUSION}

This article presents empirical evidence of the perceived risks and image of a tourist destination, based on a survey of both domestic and foreign tourists visiting Indonesia. One of the problems in contemporary tourism research is the lack of connections between the tourism industry and the possibility of a disaster. Studies argue that a disaster event in a specific tourism destination will discourage tourists from visiting (Birkland, Herabat, Little, \& Wallace, 2006; Cassedy, 1991; de Sausmarez, 2007; Drabek, 1995; Faulkner \& Vikulov, 2001; Hitchcock \& Darma Putra, 2005). Additionally, in practice, the tourism industry is confronted by many disasters and crisis events that threaten its development. 
This research has both academic and practical implications. In terms of the former, it makes an important contribution to the statement that a disaster discourages people from visiting the affected destination because of the negative perception of the risk. Based on the survey results, this paper argues that the discouragement is only temporary. An efficient recovery that provides better infrastructure and facilities could attract tourists to visit the destination. The results corroborate the statement from a previous study. Post-disaster improvement of the destination should be used as momentum for transformation that leads to better tourism industry performance (Ritchie, 2009). However, the image of the destination is important not only to attract the previous market but also to convince potential tourists. A better image may significantly impact a destination's competitiveness (Konecnik, 2004).

Meanwhile, the practical implication of the research is that tourism planners will benefit from increased awareness of the need for post-natural disaster image recovery. Planners should use the insights herein to start thinking about how to develop a new image of a safer country. Additionally, to enhance destination marketing, planners need to develop pre-trip information that allows them to identify a destination. This information should differentiate destinations from their competitors and build expectations about a planned holiday. Therefore, destination branding can assist tourists in consolidating and reinforcing their perception of a destination after their travel experience is complete.

Furthermore, this paper argues that past disaster events do not influence the decision of tourists to visit in the future. The impact is only for a short period of time, especially before the destination recovers. After recovery, destinations may be transformed in a manner that allows them to rebuild their image into a more positive one. Nevertheless, the fact remains that the existing condition of a destination is more important than its past condition. Additionally, the post-disaster re-imaging and branding strategy of the destination should be entirely coherent. This research has some limitations, especially on the aspect of bias in the tourists' answers. Since they participated during their holiday, when they were relaxed, their perception of danger might have been less critical. Therefore, future research should assess the image and perceived risk from the perspective of potential tourists. New research would enable a comparison with tourists who are already on location. Finally, natural disasters threaten tourism industry performance. Crisis recovery plans need to pay attention to rebuilding the image of an affected destination, as well as the perception of prospective tourists.

\section{REFERENCES}

Anderson, E. W., \& Sullivan, M. W. (1993). The antecedents and consequences of customer satisfaction for firms. Marketing Science, 12(2), 125-143.

Andreu, L., Bigné, J. E., \& Cooper, C. (2001). Projected and perceived image of Spain as a tourist destination for British travellers. Journal of Travel \& Tourism Marketing, 9(4), 47-67.

Baloglu, S., \& McCleary, K. W. (1999). A model of destination image formation. Annals of Tourism Research, 26(4), 868-897.

Baxter, E., \& Bowen, D. (2004). Anatomy of tourism crisis: Explaining the effects on tourism of the UK foot and mouth disease epidemics of 1967-68 and 2001 with special reference to media portrayal. International Journal of Tourism Research, 6(4), 263-273.

Beeho, A. J., \& Prentice, R. C. (1997). Conceptualizing the experiences of heritage tourists: A case study of new Lanark world heritage village. Tourism Management, 18(2), 75-87.

Beerli, A., \& Martin, J. D. (2004). Factors influencing destination image. Annals of Tourism Research, 31(3), 657-681.

Birkland, T. A., Herabat, P., Little, R. G., \& Wallace, W. A. (2006). The impact of the December 2004 Indian ocean tsunami on tourism in Thailand. Earthquake Spectra, 22(S3), 889-900.

Bramwell, B. (1998). User satisfaction and product development in urban tourism. Tourism Management, 19(1), 35-47.

Brug, J., Aro, A. R., Oenema, A., de Zwart, O., Richardus, J. H., \& Bishop, G. D. (2004). SARS risk perception, knowledge, precautions, and information sources, the Netherlands. Emergency Infection Disease, 10(8), 1486-1489.

Cai, L. A. (2002). Cooperative branding for rural destinations. Annals of Tourism Research, 29(3), 720-742.

Carter, S. (1998). Tourists' and travellers' social construction of Africa and Asia as risky locations. Tourism Management, 19(4), 349-358.

Cassedy, K. (1991). Crisis management planning in the travel and tourism industry: A study of three destination cases and a crisis management planning manual. Pacific Asia Travel Association. 
San Francisco.

Chen, R. J., \& Noriega, P. (2004). The impacts of terrorism: Perceptions of faculty and students on safety and security in tourism. Journal of Travel \& Tourism Marketing, 15(2-3), 81-97.

Chiesa, T. (2009). Navigating yet another perfect storm: The promise of sustainable travel \& tourism. The Travel \& Tourism Competitiveness Report, 97-105.

Chon, K. (1987). An assessment of images of Korea as a tourist destination by American tourists. Hotel and Tourism Management Review, 3(1), 155-170.

Chon, K. (1990). The role of destination image in tourism: A review and discussion. Tourism Review, 45(2), 2-9.

Cohen-Hattab, K., \& Kerber, J. (2004). Literature, cultural identity and the limits of authenticity: A composite approach. International Journal of Tourism Research, 6(2), 57-73.

Cronin Jr, J. J., Brady, M. K., \& Hult, G. T. M. (2000). Assessing the effects of quality, value, and customer satisfaction on consumer behavioral intentions in service environments. Journal of Retailing, 76(2), 193-218

Crompton, J. L. (1979). An assessment of the image of Mexico as a vacation destination and the influence of geographical location upon that image. Journal of Travel Research, 17(4), 18-23.

de Sausmarez, N. (2007). Crisis management, tourism and sustainability: The role of indicators. Journal of Sustainable Tourism, 15(6), 700-714.

Drabek, T. E. (1995). Disaster responses within the tourist industry. International Journal of Mass Emergencies and Disasters, 13(1), 7-23.

Echtner, C. M., \& Ritchie, J. B. (1993). The measurement of destination image: An empirical assessment. Journal of Travel Research, 31(4), 3-13.

Echtner, C. M., \& Ritchie, J. B. (2003). The meaning and measurement of destination image. Journal of Tourism Studies, 14(1), 37-48.

Ekinci, Y., \& Hosany, S. (2006). Destination personality: An application of brand personality to tourism destinations. Journal of Travel Research, 45(2), 127-139.

Faulkner, B., \& Vikulov, S. (2001). Katherine, washed out one day, back on track the next: A post-mortem of a tourism disaster. Tourism Management, 22(4), $331-344$.

Fischhoff, B. (2002). Risk perception, risk communication, risk taking. The Journal of Psychology and Financial Markets, 3(2), 102-111.

Gallarza, M. G., Saura, I. G., \& García, H. C. (2002). Destination image: Towards a conceptual framework. Annals of Tourism Research, 29(1),
56-78.

Gartner, W. C. (1989). Tourism image: Attribute measurement of state tourism products using multidimensional scaling techniques. Journal of Travel Research, 28(2), 16-20.

Gartner, W. C., \& Gartner, W. (1996). Tourism development: Principles, processes, and policies. Van Nostrand Reinhold New York.

Gartnerand, W. C., \& Hunt, J. D. (1987). An analysis of state image change over a twelve-year period (1971-1983. Journal of Travel Research, 26(2), 15-19.

Hall, C. M., \& O’Sullivan, V. (1996). Tourism, political stability and violence. Tourism, Crime and International Security Issues, 105-121.

Hallowell, R. (1996). The relationships of customer satisfaction, customer loyalty, and profitability: An empirical study. International Journal of Service Industry Management, 7(4), 27-42.

Hankinson, G. (2004). The brand images of tourism destinations: A study of the saliency of organic images. Journal of Product \& Brand Management, 13(1), 6-14.

Harrison-Walker, L. (2011). Strategic positioning of nations as brands. Journal of International Business Research, 10(2), 135-147.

Hitchcock, M., \& Darma Putra, I. N. (2005). The Bali bombings: Tourism crisis management and conflict avoidance. Current Issues in Tourism, $8(1), 62-76$.

Hosany, S., Ekinci, Y., \& Uysal, M. (2006). Destination image and destination personality: An application of branding theories to tourism places. Journal of Business Research, 59(5), 638-642.

Howie, F. (2003). Managing the tourist destination. Continuum.

Hunt, J. D. (1975). Image as a factor in tourism development. Journal of Travel Research, 13(3), $1-7$.

Hunter-Jones, P., Jeffs, A., \& Smith, D. (2008). Backpacking your way into crisis: An exploratory study into perceived risk and tourist behavior amongst young people. Journal of Travel \& Tourism Marketing, 23(2-4), 237-247.

Javalgi, R. G., \& White, D. S. (2002). Strategic challenges for the marketing of services internationally. International Marketing Review, 19(6), 563-581.

Konecnik, M. (2004). Evaluating Slovenia's image as a tourism destination: A self-analysis process towards building a destination brand. The Journal of Brand Management, 11(4), 307-316.

Kozak, M. (2001). Repeaters' behavior at two distinct destinations. Annals of Tourism Research, 28(3), 784-807. 
Kozak, M., \& Rimmington, M. (2000). Tourist satisfaction with Mallorca, Spain, as an offseason holiday destination. Journal of Travel Research, 38(3), 260-269.

Kozak, M., Crotts, J. C., \& Law, R. (2007). The impact of the perception of risk on international travellers. International Journal of Tourism Research, 9(4), 233-242.

Leiper, N. (2000). Are destinations' the heart of tourism'? The advantages of an alternative description. Current Issues in Tourism, 3(4), 364-368.

Lepp, A., Gibson, H., \& Lane, C. (2011). Image and perceived risk: A study of Uganda and its official tourism website. Tourism Management, 32(3), 675-684.

Maarif, S. (2014). Kapasitas masyarakat dan sistem kerjanya hubungannya dengan indek ketahanan dalam mengurangi risiko bencana alam. Repository.unej.ac.id.

McKercher, B., \& Pine, R. (2006). Privation as a stimulus to travel demand? Journal of Travel \& Tourism Marketing, 19(2-3), 107-116.

Moreira, P. (2008). Stealth risks and catastrophic risks: On risk perception and crisis recovery strategies. Journal of Travel \& Tourism Marketing, 23(2-4), 15-27.

Morgan, N., Pritchard, A., \& Pride, R. (2004). Destination branding: Creating the unique destination proposition. Routledge.

Morgan, N., Pritchard, A., \& Pride, R. (2011). Destination brands: Managing place reputation. Routledge.

O'Cass, A., \& Grace, D. (2003). An exploratory perspective of service brand associations. Journal of Services Marketing, 17(5), 452-475.

Park, K., \& Reisinger, Y. (2010). Differences in the perceived influence of natural disasters and travel risk on international travel. Tourism Geographies, 12(1), 1-24.

Pearce, P. L. (1988). The Ulysses factor. Evaluating Visitors in Tourist Settings. New York,

Phelps, A. (1986). Holiday destination image-The problem of assessment: An example developed in Menorca. Tourism Management, 7(3), 168-180.

Pikiran Rakyat. (2016). Kejar Target 20 juta wisman, Pariwisata Percepat Akselerasi. Retrieved from http://www.pikiran-rakyat.com/ wisata/2016/01/26/358547/kejar-target-20-juta- wisman-pariwisata-percepat-akselerasi, at 30 January 2018.

Ramseook-Munhurrun, P., Seebaluck, V., \& Naidoo, P. (2015). Examining the structural relationships of destination image, perceived value, tourist satisfaction and loyalty: Case of Mauritius. Procedia-Social and Behavioral Sciences, 175, 252-259.

Ritchie, B. W. (2009). Crisis and disaster management for tourism. Channel View Publications Bristol.

Rust, R. T., \& Zahorik, A. J. (1993). Customer satisfaction, customer retention, and market share. Journal of Retailing, 69(2), 193-215.

Sampol, C. J. (1996). Estimating the probability of return visits using a survey of tourist expenditure in the Balearic islands. Tourism Economics, 2(4), 339-351.

Sjöberg, L. (2000). Factors in risk perception. Risk Analysis, 20(1), 1-12.

Slovic, P. (2002). Perception of risk posed by extreme events (pp. 1-21). EE.UU: Decision Research/ University of Oregon.

Smith, K. (2013). Environmental hazards: Assessing risk and reducing disaster. Routledge.

Sönmez, S. F., \& Graefe, A. R. (1998). Influence of terrorism risk on foreign tourism decisions. Annals of Tourism Research, 25(1), 112-144.

Taylor, S. A., \& Baker, T. L. (1994). An assessment of the relationship between service quality and customer satisfaction in the formation of consumers' purchase intentions. Journal of Retailing, 70(2), 163-178.

United Nations World Tourism Organization (UNWTO) (2013). Press Release: International tourists to hit 1.8 billion by 2030. Retrieved from http:// media.unwto.org/en/press-release/2011-10-11/ international-tourists-hit-18-billion-2030 at 1 January 2018.

Weinstein, N. D. (1988). The precaution adoption process. Health Psychology, 7(4), 355.

Woodside, A. G., \& Sherrell, D. (1977). Traveller evoked, inept, and inert sets of vacation destinations. Journal of Travel Research, 16(1), 14-18.

Yoon, Y., \& Uysal, M. (2005). An examination of the effects of motivation and satisfaction on destination loyalty: A structural model. Tourism Management, 26(1), 45-56. 